\title{
WARIS DAN WASIAT \\ DALAM PERTENTANGAN AYAT AL-QUR'AN
}

Oleh: Syuhada,*

\begin{abstract}
Human entrusted property as ruler of the world. So entrusted to death, the property back into the hands of the Lord automatically. Because God does not accept the property, then given to families designated by the rules of revelation. Setting the rules of media ownership property with inheritance and probate. In the verses of inheritance and will appear in which contradict each other to remove the provision. While it is believed that there are verses in the Qur'an which have been removed so that it does not work, including the verses of inheritance and wills. By placing verse as wills and testaments muhkamah verse as a compromise with the Hadith mukhassis not make erase status and erased in the verses of the Koran. Elimination Naskh supported by state law to decrease gradually in terms of the condition of society. With inheritance and probate law as set out in the passage suggests that-naș inheritance and probate law are interrelated and complementary.
\end{abstract}

Keywords: Inheritance, Wills, Conflict Clause.

Dosen Prodi Ahwal Syakhsiyyah Fakultas Syari'ah Sekolah Tinggi Islam Bani Fatah Tambakberas Jombang. 


\section{Pendahuluan}

Islam memandang harta adalah milik Allah SWT semata, sedangkan manusia ditunjuk sebagai penguasanya. Begitu yang diamanati meninggal dunia, harta kembali ke tangan Tuhan secara otomatis. Karena Tuhan tidak menerima harta, maka diberikan kepada keluarga yang ditunjuk dengan aturan wahyu. Apakah penunjukan dan ketentuan waris itu berdasar budaya Arab yang memang tempat wahyu turun sehingga waris hanya berlaku lokal, atau sebuah aturan universal yang dipilih Tuhan dan kebetulan banyak kesamaan dengan budaya Arab sehingga hukum waris berlaku umum, dengan memperhatikan data wahyu para ulama cenderung memilih dengan pola pikir universal bahwa hukum waris berlaku umum, bukan untuk lokal Arab saja.

Waris dalam Islam bukanlah pembagian murni rasional, melainkan banyak bermuatan paket tawqifiyat). Ada berbagai aturan menyangkut harta pusaka dan pewaris. Dari sebab pewarisan, rukun pewarisan, penghalang pewarisan, dan lainlain.

Secara umum pembagian waris menitikberatkan pada garis keturunan ayah dan jenis kelamin laki-laki. Ahli waris ini diberi titel "qurb" dan "quwwah". Inilah yang paling kuat dan diprioritaskan dalam perolehan harta pusaka, yang umumnya laki-laki mendapat dua kali bagian wanita. Mengapa? Studi syari'ah tentang rasionalisasi dan keterkaitan waris menunjuk adanya padu aturan antara waris perolehan) dan tanggung jawab "nafaqah" atau beban keluarga. Laki-laki dibebani memberi nafkah kepada keluarga atau anak laki-laki ditunjuk sebagai penangung jawab urusan keluarga. Itu artinya ia harus menghidupi diri dan mencukupi orang lain keluarga) sehingga berkewajiban ganda. Sedangkan wanita dalam Islam tidaklah demikian. Ia cenderung dilayani kaum lelaki. Wajar kiranya bila laki-laki ditunjang subsidi, karena tanggung jawab luar dirinya. Dasar pemikiran inilah yang mendukung pandangan universal dan sekaligus menguatkan pembagian dua banding satu.

Harta mayit sebenarnya tidak hanya diatur dengan waris saja. Ada yang disebut “wasiah" yang diperuntukkan selain ahli waris, atau keluarga yang secara pewarisan terhalang tidak mendapat apa-apa tetapi dia sangat membutuhkan dan termasuk keluarga dekat tetapi tidak kuat. Ayat-ayat waris 
dalam al-Qur'an menunjuk pembagian secara lengkap. Dengan bagian waris ini, para ahli waris tidak lagi berhak mendapatkan wasiat, karena wasiat untuk orang luar, selain ahli waris. Ternyata dalam ayat wasiat pada al-Baqarah : 180 disebutkan bahwa wasiat itu diberikan kepada kerabat atau al-aqrabin. Ada pertentangan dalam ketentuan waris dan wasiat dalam ayat alQur'an. Oleh karena itu, dalam tulisan berikut akan dibahas mengenai waris dan persoalan wasiat yang tampak bertentangan dengan asumsi bahwa tidak mungkin terjadi pertentangan pada apa yang telah diwahyukan Allah dalam alQur'an.

\section{Pembahasan}

\section{Pewarisan Dalam Islam}

Teks Al-Qur'an dan al-Hadith mengenai ketentuan waris sangat terbatas dan global. Kedua sumber itu telah mengatur bagian-bagian ahli waris secara tegas, sehingga dikenal dengan sebutan al-furū pasti), selain yang mendapat bagian sisa 'asabah). Adanya aturan bagian-bagian ahli waris secara tegas menjadikan perselisihan antara ahli waris dari pewaris dapat diselesaikan. Oleh karena itu, ayat tentang bagian ahli waris tergolong ayat yang petunjuknnya pasti atau tegas dalālah qat'iyyah).

Ayat waris terdapat dalam al-Nisä' : 11, 12 dan 176, al-Anfal : 75, dan al-Ahzab: 6 menunjuk pembagian secara lengkap, baik fard separo, sepertiga, dua pertiga, seperempat, seperenam dan seperdelapan), maupun ta șíb atau bagian sisa. Juga ditunjuk pribadi pewaris yang menerima, baik dari sisi aṣl orang tua), yakni ayah, ibu kakek dan nenek atau far' anak cucu) atau hawāshi sektor saudara) atau suami-istri.

Status waris adalah hak, bukan kewajiban. Artinya ketentuan waris tidaklah mengikat mutlak dan tidak tertawar. Karena menyangkut hak, seseorang dianjurkan berdamai lebih dahulu dalam pembagian harta waris. Disunnahkan bertanazul tidak mengambil haknya) untuk diberikan kepada yang lebih membutuhkan. Baru setelah kondisi tidak mengizinkan berbaikan, maka ketentuan 
waris diberlakukan dan masing-masing pewaris wajib tunduk terhadapnya.

Teknik izdiham saat ahli waris dari berbagai keluarga ada semua), dibutuhkan rasionalisasi yang tertumpu pada ketajaman ijtihad. Maka banyak pandangan perihal pembagian waris antara seorang sahabat Nabi dengan sahabat lainnya. Muncul istilah "gharrawain" Zaid bin Tsabit sahabat yang oleh Nabi ditunjuk secara khusus sebagai paling menguasai persoalan Faraidh), "Musyarakah" Umar bin al-Khattab, "Mimbariyah" Ali bin Abi Thalib, dan lain-lain. Ketajaman ijtihad lebih-lebih diperlukan ketika masalah waris telah jatuh di belantara pemikiran para mujtahid. Meski begitu tidak satupun ulama yang mempermasalahkan pembagian pokok yang telah ditentukan nash semisal setengah, duapertiga, sepertiga, seperempat, seperenam dan seperdelapan.

Dalam Fiqh Islam dikenal empat sebab milik yaitu aqad transaksi), khalafiyah pewarisan), tawallud perkembangan harta milik) dan ihraz mubahat penangkapan benda umum). Sebagai salah satu cara mendapatkan harta secara halal ditegaskan, warisan diperoleh karena:

a. Hubungan kerabat khusus, yang bukan tergolong kerabat dhawi al-arhām, disebut juga dengan nasab hakiki.

b. Akad nikah yang sah walaupun belum disetubuhi,

c. Waris wala $\bar{a}^{\prime}$ atau mendapatkan warisan karena memerdekakan budak, disebut juga dengan nasab hukmi, ${ }^{1}$

Tiga hal diatas oleh Zakariya al-Anșāri disebut sebagai sebab khusus mengingat ada sebab umum dimana seseorang berhak mendapat warisan yaitu beragama Islam. ${ }^{2}$

Dalam hal lain bergandeng dengan perolehan harta dari orang yang telah meninggal, wasiat diterimakan kepada selain ahli waris baik sebagai ahli waris dengan nasab hakiki, akad nikah, maupun nasab hukmi. ${ }^{3}$

\footnotetext{
${ }^{1}$ Aḥmad 'Abd al-Jawād, Ușūl 'Ilm al-Mawārith, Cet. II, (Beirut : Dar alJayl, 1986), 1-2.

${ }^{2}$ Zakariya al-Ansari, Sharh al-Tahrir. (Surabaya: Maktabat Salim b. Sa'ad b. Nabhan, t.th), 86-87.

${ }^{3}$ Ibid., 32-33.
} 
Adapun sebab-sebab seseorang tidak mendapatkan warisan, yang disepakati para ulama ada 3 tiga), yaitu perbudakan, pembunuhan, dan berlainan agama. Sedangkan, sebab berlainan negara atau bangsa sebagaimana dicantumkan oleh Sayyid Sabiq dalam kitabnya, Fiqh al-Sunnah, tidak menjadi penghalang mendapatkan warisan antara sesama orang Islam. ${ }^{4}$

\section{Wasiat Dalam Islam}

Wasiat merupakan salah satu cara peralihan harta kewarisan) antar generasi ke generasi yang diakui selama tahun-tahun awal Islam sampai saat ini. Dalam al-Qur'an disebutkan bahwa harta tidak boleh dibagi sebelum dipenuhi semua wasiat mūsi. Penunjukan wasiat harus dilaksanakan lebih dahulu sebelum harta peninggalan mayyit dibagikan kepada ahli waris, bahkan lebih didahulukan daripada pemenuhan pembayaran hutang, merupakan pesan sangat kuat terhadap persoalan wasiat.

Kata wasiat dalam bahasa Indonesia berasal dari kata dalam bahasa Arab al-wașiyyah, yang diidentikkan dengan kata al-ị̦á, dan al-wiṣayah. Kata al Wașiyyah dalam pengertian bahasa lughah) diambil dari kata "wașsă alshay'a bikadhā, yang bermakna al-ịsāl, menyampaikan sesuatu, karena kebaikan amal dari orang yang berwasiat sewaktu di dunia akan dibalas dengan kebaikan di akhirat. ${ }^{5}$ Juga bermakna suatu perjanjian yang dilakukan seseorang kepada orang lain untuk melakukan sesuatu perbuatan, baik sewaktu masih hidup atau setelah meninggal dunia. ${ }^{6}$ Dalam pengetian istilah, wasiat merupakan pemberian milik yang disandarkan waktunya terjadinya perpindahan milik), setelah pemberi wasiat meninggal dunia, baik itu berupa benda atau manfaat dari suatu benda. Dengan demikian, dapat dipahami bahwa wasiat harus mengandung unsur :

a. Al-șighah at au pernyataan kehendak.

\footnotetext{
${ }^{4}$ Sayyid Sabiq, Fiqh al-Sunnah. Vol.3. (Beirut: Dar al Fikr, 1977), 427.

${ }^{5}$ Zakariya al-Ansari, Sharh al-Tahrir, 73

${ }^{6}$ Wahbah al-Zuhayli, al-Fiqh al-Islām wa Adillatuh, vol. 9. (Libanon: Dar alFikr, 1997), 8.
} 
b. Al-musssi atau orang yang mewasiatkan, yang melakukan $\overline{i j a b}$ dalam wasiat dengan menyebut materi wasiat dan sasaran wasiat,

c. Mussa $\bar{a}$ lah atau orang yang melakukan qabul dalam wasiat sebagaimana yang dinyatakan oleh müsis, dan

d. Al-mụșa bih atau obyek yang berupa harta atau manfaat harta. ${ }^{7^{\circ}}$

Kitab-kitab fiqh dalam pembahasannya tentang wasiat selalu berdampingan dengan pembahasan waris. Berikut disajikan contoh bahasan-bahasan waris dan wasiat dalam kitab fiqh.

a. Kitab Fath al-Qarib al-Mujib karya al-Ghazi lebih dahulu membicarakan bab waris dan kemudian membicarakan bab wasiat.

b. Kitab al-sharqawi 'ala al-tahrir, karya al-Sharqawi, alFiqh al-Islami wa Adillatuh, karya al-Zuhayli, dan Fiqh al-Sunnah karya Sayyid Sabiq membahas wasiat lebih dahulu daripada pembahasan tentang waris.

Hal ini secara tidak langsung menunjukkan bahwa obyek wasiat adalah berupa harta benda, bukan perintah melalukan suatu perbuatan yang tidak berupa harta benda. Untuk itu, pelaksanaan wasiat adalah terkait dengan harta tinggalan dan dikeluarkan terlebih dahulu, sebelum pembagian warisan.

Dengan melihat pernyataan bahwa wasiat akan efektif setelah müsis meninggal dunia, maka akad wasiat merupakan akad yang sah jika sudah terpenuhi unsurunsurnya, tetapi belum dapat dikatakan efektif lāzim) selama mūssi belum meninggal dunia. Artinya, müsis dapat mencabut kembali jika menghendaki asalkan dia masih hidup, karena wasiat merupakan 'aqd ghayr lazim, akad yang tidak langsung efektif berlaku. ${ }^{8}$

Obyek wasiat adalah benda atau manfaat dari benda, bukan lainnya. Jika obyek wasiat itu berupa selain harta benda, maka itu didasarkan pada makna umum kata "khayr", yang bermakna sesuatu yang baik, bukan yang haram atau maksiat Jika diartikan dengan harta benda,

${ }^{7}$ Al-Sharbini, al-Iqna', vol.2, 109.

${ }^{8}$ Ibid., 54.

Tafaqquh; Vol. 1 No. 2, Desember 2013 
maka makna tersebut diambil dari kata "khayr" dengan makna harta benda $\overline{m a l}$ ), sebagaimana Imam Mujahid menyatakan seluruh kata "khayr" dalam al Qur'an bermakna $m \bar{a} l^{9}$

Pensyariatan wasiat bagi umat Islam tidak lepas dari salah satu tujuan wakaf, dan tujuan berderma lain dalam Islam, yaitu :

a. Wasiat merupakan salah satu amal yang dilakukan oleh seseorang untuk mendekatkan diri kepada Allah qurbah) di akhir hayatnya, agar kebaikannya bertambah atau untuk menutupi kekurangan-kekurangan amal yang telah ditinggalkan, dan

b. Wasiat sebagai amal baik seseorang kepada orang lain, sekaligus memupuk rasa kasih sayang antara sesamanya. $^{10}$

Tujuan tersebut tidak lepas bahwa, manusia semasa hidupnya tidak lepas dari perbutan-perbuatan yang tidak sesuai dengan aturan-aturan agama atau sekedar melakukan kewajiban secara pas-pasan. Di samping itu, manusia perlu menjalin hubungan dengan sesamanya, apalagi kepada generasi penerus berikutnya dan masih ada hubungan keluarga, sehingga mereka tidak sebagai generasi yang lemah sebagaimana diamanatkan dalam al-Nisa! 9 :

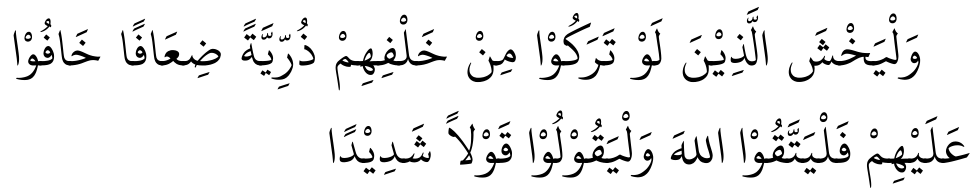

"Dan hendaklah takut kepada Allah orang-orang yang seandainya meninggalkan di belakang mereka anak-anak yang lemah, yang mereka khawatir terhadap kesejahteraan) mereka. Oleh sebab itu hendaklah mereka bertakwa kepada Allah dan hendaklah mereka mengucapkan Perkataan yang benar."

Kesejahteraan tidak dapat lepas dari harta benda, sebab harta benda merupakan alat yang dapat menstabilkan kehidupan seseorang, sehingga dapat membangun sarana

\footnotetext{
${ }^{9}$ Wahbah al-Zuhayli, Fi al-'Aqīdah wa al-Sharì'ah wa al-Manhāj, vol. 2, (Beirut: Dar al Fikr, 1991), 118.

${ }^{10}$ Sayyid Sabiq, Fiqh al-Sunnah, vol.3, 416
} 
ibadah dan menuntut ilmu, sebagiamana ditegaskan dalam al Nisăt: 5, dengan disifati "allatì ja'ala allah lakum qiyāma".

Para ulama berbeda pendapat tentang apakah hukum wasiat dalam berbagai pendapat. Di antaranya adalah :

a. Wajib berwasiat bagi orang yang mempunyai harta benda, baik sedikit maupun banyak, sebagimana pendapat al-Zuhri dan Abu Mihlaz. Hal ini senada dengan dengan pendapat Ibn Hazm, yang menyatakan wajib sebagaimana riwayat yang telah diterimanya dari Ibn 'Umar, Talhah, al-Zubayr, Abd. Allah ibn Abi Awfa, Talhah ibn Mutarrif, Țāwus, dan al-Sha'bi. Mereka menggunakan dalil firman Allah dalam al Baqarah : 180.

b. Wajib berwasiat kepada kedua orang tua bapak/ibu) dan para kerabat yang tidak mendapatkan bagian warisan dari mayyit, sebagiamana pendapat Masruq, Iyas, Qatadah, Ibn Jarir dan al-Zuhri.

Berwasiat tidak wajib bagi orang yang tidak meninggalkan harta benda sebagimana pendapat pertama, dan tidak wajib kepada kedua orang tua dan para kerabat yang tidak mendapatkan warisan, sebagaimana pendapat kedua. Akan tetapi, hukum wasiat bergantung pada keadaannya. Hukum itu dapat menjadi wajib, sunnah, haram, makruh, atau bahkan ibahah boleh). ${ }^{11}$

Dasar adanya syariat wasiat dalam Islam dapat dilihat dari enam ayat yang turun tentang wasiat. Yaitu :

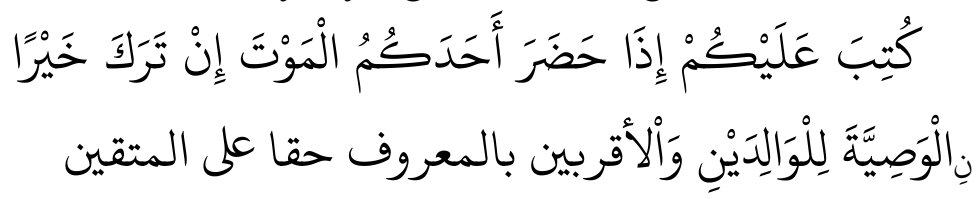

"Diwajibkan atas kamu, apabila seorang di antara kamu kedatangan tanda-tanda) maut, jika ia meninggalkan harta yang banyak, Berwasiat untuk ibubapak dan karib kerabatnya secara ma'ruf, ini adalah) kewajiban atas orang-orang yang bertakwa."

${ }^{11}$ Ibid., 416-417. 
فَمَنْ بَدَّلَهُ بَعْدَ مَا سَمِعَهُ فَاِنَّمَا إِثْمُهُ عَلَ الَّذِيْنَ يُبَبِدِلْونَهُ

$$
\text { إِنَّ اللََ سَمِيْعُ عَلِيْمَ }
$$

"Maka Barangsiapa yang mengubah wasiat itu, setelah ia mendengarnya, Maka Sesungguhnya dosanya adalah bagi orang-orang yang mengubahnya. Sesungguhnya Allah Maha mendengar lagi Maha mengetahui."

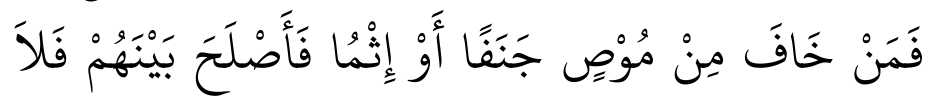

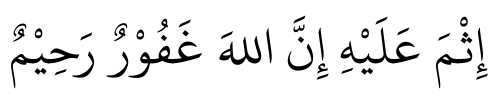

“(Akan tetapi) Barangsiapa khawatir terhadap orang yang Berwasiat itu, Berlaku berat sebelah atau berbuat dosa, lalu ia mendamaikan antara mereka, Maka tidaklah ada dosa baginya. Sesungguhnya Allah Maha Pengampun lagi Maha Penyayang"

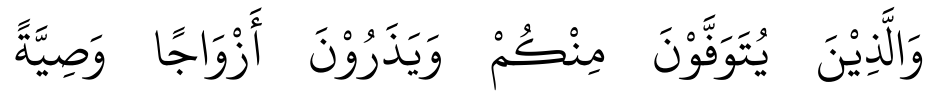

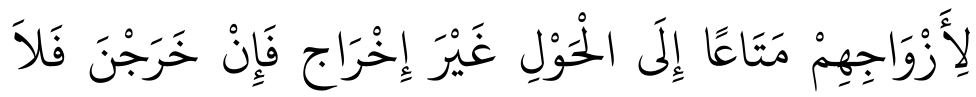

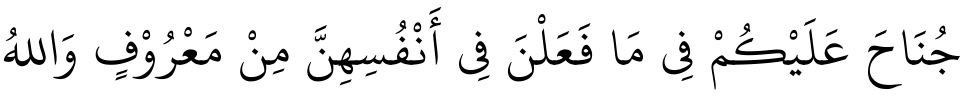
عَزْيْز حَكِيْمَ

"Dan orang-orang yang akan meninggal dunia di antara kamu dan meninggalkan isteri, hendaklah Berwasiat untuk isteri-isterinya, yaitu) diberi nafkah hingga setahun lamanya dan tidak disuruh pindah dari rumahnya). akan tetapi jika mereka pindah sendiri), Maka tidak ada dosa bagimu wali atau waris dari yang meninggal) membiarkan mereka berbuat yang ma'ruf terhadap diri mereka. dan Allah Maha Perkasa lagi Maha Bijaksana"

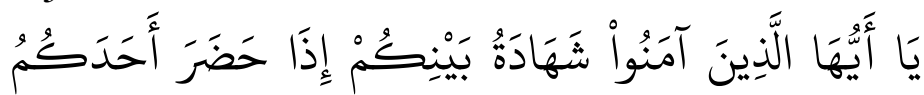

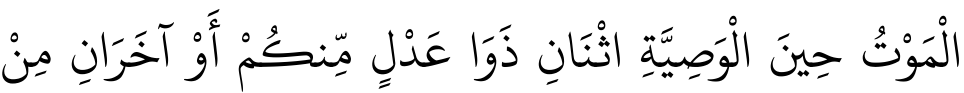




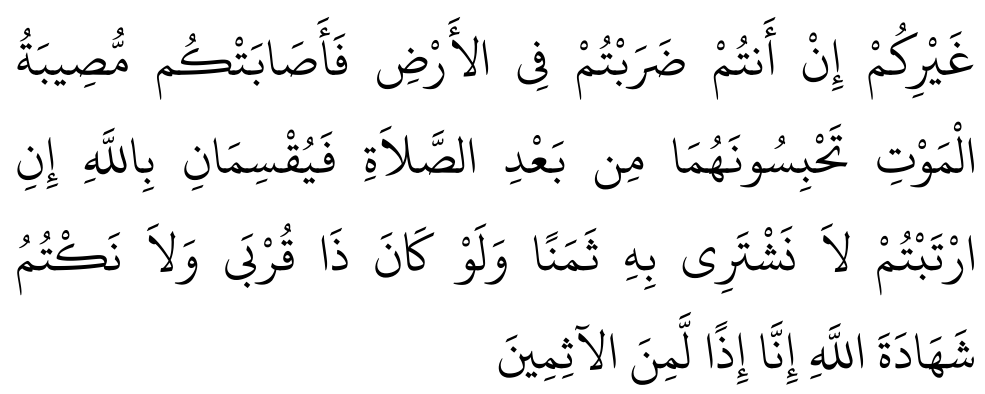

"Hai orang-orang yang beriman, apabila salah seorang kamu menghadapi kematian, sedang Dia akan berwasiat, Maka hendaklah wasiat itu) disaksikan oleh dua orang yang adil di antara kamu, atau dua orang yang berlainan agama dengan kamu, jika kamu dalam perjalanan dimuka bumi lalu kamu ditimpa bahaya kematian. Kamu tahan kedua saksi itu sesudah sembahyang untuk bersumpah), lalu mereka keduanya bersumpah dengan nama Allah, jika kamu ragu-ragu: "Demi Allah) Kami tidak akan membeli dengan sumpah ini harga yang sedikit untuk kepentingan seseorang), walaupun Dia karib kerabat, dan tidak pula) Kami Menyembunyikan persaksian Allah; Sesungguhnya Kami kalau demikian tentulah Termasuk orang-orang yang berdosa."

Secara berurutan dapat dikatakan bahwa diantara pesan ayat-ayat di atas adalah:

a. Al-Baqarah: 180, memerintahkan orang yang mendapati tanda-tanda datangnya maut untuk meninggalkan wasiat bagi ibu, bapak, dan kerabat.

b. Al-Baqarah: 181, menyerahkan pertanggungan dosa orang yang mengubah wasiat kepada Allah.

c. Al-Baqarah: 182, mendorong rekonsiliasi dengan pihakpihak yang tidak setuju dengan pembagian warisan.

d. Al-Baqarah: 240, mengizinkan orang yang berwasiat untuk membuat ketetapan bahwa jandanya diberi nafkah maksimum setahun dan membiarkan tinggal dirumah almarhum suaminya. 
e. Al-Maidah: 106, bahwa agar wasiat itu valid harus dibuat di hadapan dua orang saksi yang terpercaya. ${ }^{12}$

Enam ayat ini merefleksikan suatu sistem waris melalui wasiat yang relatif membebaskan orang untuk menentukan siapa saja ahli warisnya dan berapa banyak mereka yang akan memperoleh bagian. Sistem waris yang bebas ini kemudian diakhiri dengan turunnya al-Maidah: 11-12 dan 176 yang menentukan siapa ahli waris dan berapa banyak mereka mewarisi. ${ }^{13}$

Dalam Hadis kewenangan wasiat kemudian dibatasi bahwa wasiat itu tidak boleh lebih dari sepertiga warisan. Pembatasan ini umumnya difahami sebagai satu usaha untuk menciptakan keseimbangan antara aspek sukarela dan aspek wajib dari hukum waris. Minimal dua pertiga warisan dibagi-bagikan menurut aturan-aturan wajib dalam ayat-ayat waris, maksimal sepertiga warisan dapat digunakan untuk wasiat bebas. ${ }^{14}$

\section{Wasiat Dalam al-Qur'an}

Al-Qur'an menggunakan kata wasiyyat dan derivasinya untuk menunjuk berbagai hal. ${ }^{15}$ Di antaranya adalah tentang penerusan kepemilikan harta dari orang yang telah meninggal dunia kepada orang lain.

Terdapat berbagai macam sifat ayat dalam al-Qur'an. Dari materinya, ada ayat ahkām atau ayat hukum atau ayat-ayat yang bermuatan hukum Islam atau syari'ah Islam atau fiqih dan ada ayat yang bermuatan selain hukum. Ayat bermuatan hukum yaitu ayat yang menjelaskan hukum perbuatan manusia, dari yang diperintahkan, yang dilarang atau yang sekedar dibolehkan. Sedangkan ayat yang bermuatan selain hukum adalah seperti keimanan, sosial, politik, ilmu pengetahuan, sejarah dan lain-lain.

Ulama berbeda pendapat tentang keberadaan alBaqarah: 180, apakah ia tergolong ayat yang mansūkhah dihapus atau tidak berlaku) atau muhkamah tetap berlaku).

${ }^{12}$ David S Power Peralihan Kekayaan dan politik Kekuasaan Kritik Historis Hukum Waris. (Jogjakarta: LKiS, 2001), 14

${ }^{13}$ Ibid., 63

${ }^{14}$ Ibid., 183

${ }^{15}$ Ibn Mandhur, Lisan al- 'Arab. Juz 15, (Beirut: Dar Sadir, t.th), 394. 
Naskh, jika dipandang benar adanya dalam al-Qur'an seperti pendapat jumhur ulama, maka hanya boleh terjadi pada ayat-ayat hukum saja, dengan syarat-syarat tertentu sebagaimana diatur dalam kitab-kitab Ușul al-Fiqh. Sedangkan semisal ayat aqidah atau sejarah tidak boleh ada naskh. $^{16}$

Ada tiga jenis naskh terkait terkait postur ayat mansūkhah, yaitu : pertama, naskh al-hukm dūna al-rasm penghapusan terhadap pesan hukum sebuah ayat tanpa menghilangkan fisiknya). Kedua, naskh al-rasm dūna alhukm penghapusan fisik ayat saja dengan tetap memberlakukan pesan hukumnya) dan ketiga, naskh alrasm wa al-hukm penghapusan total terhadap fisik ayat dan kandungan hukumnya). ${ }^{17}$

Terhadap ayat kaji al-Baqarah : 180) ulama berbeda pendapat tentang apakah ia tergolong ayat yang mansükhah kategori naskh al-ḥukm dūna al-rasm atau muhkamah dalam pandangan sebagai berikut:

a. Ayat tersebut muhkamah, yang secara lahir menunjukkan umum, tetapi maknanya khusus untuk kedua orang tua yang tidak menerima warisan seperti orang kafir dan budak, dan kerabat yang tidak tergolong ahli waris. Pendapat ini sebagaimana pendapat ibn 'Abbās, Ḥasan Basri, Dahāk, Țawus, Masruq, Muslim ibn Yasar dan al-'Ala' ibn Ziyad. Pendapat ini merupakan pendapat yang dipilih Ibn Jarir al-Tabari. ${ }^{18}$

Dalam versi lain dijelaskan bahwa wasiat kepada kedua orang tua dan kerabat ahli waris telah dinasakh dihapus dan tidak berlaku), sedangkan kerabat yang bukan ahli waris tetap wajib dilaksanakan. Hal ini, karena wasiat diwajibkan berdasarkan ayat tersebut, baik yang mendapatkan warisan maupun yang tidak. Akan tetapi, kemudian wasiat kepada ahli waris dinasakh dan kepada bukan ahli waris tetap berlaku.

\footnotetext{
16 'Abd al-Karìm Zaydan, al-Wajīz fi Ușūl al-Fiqh. (Beirur: Muassasat alRisalah, t.th.), 387.

${ }^{17}$ Hibātullāh Ibn Salamah, al-Nāsikh wa al-Mansūkh (Beirut : 'Alam alKutub, t.th.), 10.

${ }^{18}$ Al-Qurtubi, al Jami li Ahkam al Qur'an.vol.2. Mesir: Dar al-Kutub al'Arabiyah wa Nashr, 1967), 262.
} 
Namun demikian, al-Tabari menyebutnya bukan dengan istilah "nasakh", tetapi disebut dengan takhṣiṣ sebagaimana pendapat ulama muta'akhir.

b. Ibn Umar, Abū Mūsa al-Ash'āri, dan Sa'ad ibn Musayyab berpendapat bahwa ayat al-Baqarah: 180 telah dinasakh oleh ayat mawārith dalam al Nisa:11, baik kepada orang yang menerima warisan atau tidak. Hal ini berdasarkan dalil yan diriwayatkan dari al-Shafi'i dari Imran ibn Hushayn bahwa Rasulullah SAW telah menetapkan hukum terhadap enam budak yang dimiliki seorang lak-laki yang tidak mempunyai harta benda, selain budak yang dimerdekakan dan dia telah meninggal dunia. Kemudian, beliau membaginya menjadi tiga bagian, yang dua dimerdekakan dan yang empat tetap menjadi budak. Dalam hal ini, jika wasiat itu kepada kerabat dan batal untuk lainnya, maka beliau tidak akan membolehkan wasiat tentang dua hamba, karena merdekanya kedua budak tersebut berdasarkan wasiat, padahal keduanya tidak tergolong kerabat.

c. Al-Razi dalam tafsirnya, Mafätị al-Ghayb, menceritakan dari Abu Muslim al Asfahani, bahwa ayat ini muhkamah, tidak dinasakh. Ia ditafsirkan dengan ayat mawärith, sehingga maknanya bahwa Allah mewajibkan apa yang diwasiatkan Allah mendapatkan warisan bagi kedua orang tua dan kerabat sebagaimana dalam al Nisa:11). Alasan yang ditampilkan dalam peniadaan naskh ayat ini adalah:

1) Ayat ini tidak berlawanan dengat ayat mawarith, tetapi, bahkan ia menetapkan dan bahkan memperkuatnya.

2) Sesungguhnya tidak ada saling meniadakan antara berlakunya wasiat kepada kerabat dan pewarisan. Dalam hal ini, wasiat merupakan pemberian dari orang yang akan meninggal, sedangkan pewarisan merupakan pemberian dari Allah. Dengan demikian, ahli waris dapat memperoleh wasiat dan pewarisan melalui hukum yang terdapat dalam kedua ayat tersebut.

3) Jika saja diperkirakan terjadi saling meniadakan antara ayat wasiat dan warisan, maka sebenarnya 
dapat dipahami bahwa ayat mawarith berfungsi sebagai takhsis terhadap ayat wasiat. Hal ini dapat dipahami bahwa ayat 180 al-Baqarah secara umum menunjukkan bahwa wasiat itu wajib untuk setiap kerabat. Sementara itu, ayat mawārith mengeluarkan kerabat yang ahli waris sebagai mukhașsis). Oleh karena itu, ayat tentang wasiat ini mengarah pada kerabat yang tidak sebagai ahli waris, karena ada penghalang mendapatkan warisan seperti kafir beda agama), budak; terhalang ahli waris yang lebih dekat mahjüb), dan tergolong dhawi al-arḥam, keturunan anak perempuan. ${ }^{19}$

Menyikapi perbedaan status ayat waris dan wasiat di atas, sesungguhnya larangan wasiat untuk ahli waris itu bukan diatur oleh Al-Qur'an, melainkan oleh Hadits yaitu: ${ }^{20}$

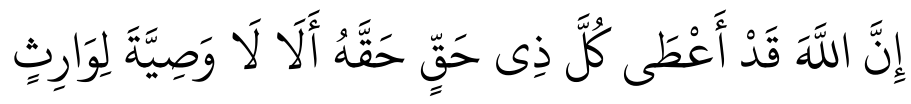

"Sesungguhnya Allah memberi setiap sesuatu sesuai dengan haknya. Ingatlah bahwa ahli waris tidak berhak atas wasiat"

Dengan adanya Hadis ini, terdapat tiga naș yang mengatur soal waris kaitannya dengan wasiat. Wasiat adalah pesan pemberian materi untuk seseorang atau badan yang dilaksanakan setelah pemberi pesan meninggal dunia. $^{21}$ Sedangkan warisan merupakan peralihan hak milik secara otomatis dari mayit kepada ahli waris dengan syarat-syarat tertentu. ${ }^{22}$

Sebelum Islam datang mengatur soal harta waris, masyarakat Arab sudah melakukan pembagian harta tersebut menurut cara mereka sendiri, termasuk wasiat. Pada awal Islam, orang tua dan kerabat dekat sering kali

${ }^{19}$ Muhammad Fakhruddin al-Razi. Mafatih al-Ghayb. Vol.3. (Beirut: Dar al Fikr, 1994), 67; Muhammad Ali al-Sayis, Tafsir Ayat al-Ahkam, vol.1(Mesir: Muhammad Ali Subayh, t.th.) 56-57.

${ }^{20}$ Muhammad ibn Yazid al-Qazwini Ibn Mājah, Sunan Ibn Mājah, Tahquīq : Nāsìr al-Dīn al-Albāni (Riyad : Maktabah al-Ma'ārif li al-Nashr wa alTawzi', t.th.), 461.

${ }^{21}$ Al-Jurjāni, al-Ta'rifat (Mesir : Maṭba'ah al-Ḥamidiyah, t.th.), 174.

${ }^{22}$ Ibid. 
tidak mendapatkan perhatian soal ini. Hal itu karena ada tradisi lain yang lebih mengikat, seperti perjanjian atau half atau sumpah setia menjadi saudara yang saling bisa mewarisi. Untuk itu, al-Qur'an hadir mempertegas hak orang tua dan kerabat dekat dengan ayat wasiat ini.

Setelah Islam menguat dan mental pemeluknya semakin siap menerima perintah agama, maka turun ayatayat waris yang lebih mempetegas bagian orang tua dan keluarga terdekat. Dengan pembagian waris seperti diatur tersebut, maka Hadis hadir mempertegas, bahwa ahli waris tidak lagi diperbolehkan menerima wasiat. Dengan demikian, ketiga nașs tersebut saling terkait dan melengkapi.

Kini persoalan pada sosok ahli waris yang tidak mendapat bagian karena mahjūb atau terhalang secara shar'iy, apakah ahli waris tersebut diperbolehkan menerima wasiat ? Dilihat dari sisi esensial dan tujuan penyebaran pembagian harta, maka dibolehkan. Dengan pandangan ini, maka sesungguhnya ayat wasiat tersebut bisa dipakai dasar bagi ahli waris yang tidak mendapat bagian waris karena mahjub atau suqūt, gugur secara shar'iy. Gugurnya ahli waris tersebut karena satu di antara tiga mawāni' al-irth, yakni al-qatl membunuh, baik sengaja atau tidak), ikhtiläf al-din perbedaan agama antara mayit dengan ahli waris) dan al-riqq berstatus sebagai budak). ${ }^{23}$

Dari sini, ayat wasiat juga bisa dipakai sebagai dasar diberlakukanya "wașiyyat wäjibah" atas setiap mayit. Bahwa setiap orang beriman wajib mewasiatkan sebagian hartanya kepada orang lain selain ahli waris, atau kepada ahli waris yang mahjūb tersebut. Hakim, dengan kewenangannya wajib memutuskan adanya wasiat wasiyyat wäjibah), meskipun mayit yang bersangkutan tidak pernah berwasiat. Sehingga wasiat bukan lagi merupakan perbuatan suka-suka bagi setiap orang yang akan meninggal, melainkan merupakan kewajiban yang melekat pada diri setiap orang dan harus dilaksanakan, baik oleh keluarga maupun hakim setempat.

${ }^{23}$ Aḥmad 'Abd al-Jawād, Uṣūl 'Ilm al-Mawārith, 3-4. 
Ketentuan wasiat wajibah merupakan hasil ijtihad para ulama dalam menafsirkan surat al-Baqarah : 180 yang berintikan pada rasa keadilan dan kemanusiaan. Karena bisa jadi orang yang ditinggal mati itu sama-sama dekat dekat mayit tapi yang satu mendapat warisan sedangkan yang satunya tidak mendapat warisan. Seperti dalam kasus seorang meninggal dunia meninggalkan istri dan satu orang cucu laki dari anak laki-laki dan satu cucu perempuan dari anak perempuan. Istri mendapat seperdelapan dari harta, satu cucu laki-laki dari anak laki-laki mendapat ashobah dan satu cucu perempuan dari dari perempuan mahjub. Karena cucu dari pihak perempuan ini tidak mendapatkan warisan padahal dia sama-sama cucu mayit, maka demi rasa keadilan maka baginya wasiat wajibah dengan jumlah tidak lebih dari sepertiga harta peninggalan.

Wasiat wajibah pertama kali muncul di Mesir. Kemunculan ini akibat dari pergeseran antara hukum Islam dan hukum Barat. Dimana dalam hukum Barat tidak ada perbedaan jender. Tidak membedakan antara ahli waris perempuan dan laki-laki. Sedangkan dalam hukum Islam masih membedakan antara laki-laki dan perempuan. Karenanya kemudian dalam hukum Mesir hakim diberi kewenangan untuk memberikan harta pusaka melalui wasiat wajibah kepada ahli waris yang tidak mendapatkan warisan.

Wasiat wajibah ini kemudian berlaku di berbagai negara seperti Pakistan, Tunisia, Syiria, Maroko dan Indonesia. Di Mesir orang yang berhak menerima wasiat wajibah adalah cucu atau para cucu keturunan anak perempuan generasi pertama) dan keturunan anak laki-laki seluruh generasi) - bukan penerima warisan-yang orang tuanya meninggal telah lebih dahulu meninggal dari si pewaris. Di Maroko dan Suriah yang mendapat wasiat wajibah hanyalah para cucu dan seterusnya kebawah) dari keturunan anak laki-laki. Cucu dari anak perempuan tidak mendapatkan wasiat. Sedangkan di Maroko penerima wasiat wajibah adalah cucu baik laki-laki maupun 
perempuan dari anak laki-laki maupun perempuan pada tingkat pertama. $^{24}$

Di Indonesia, wasiat wajibah sebagaimana diatur dalam Kompilasi Hukum Islam pada pasal 209 bukan hanya untuk para cucu tapi juga untuk anak angkat dan bapak angkat. yang dimaksud dengan anak angkat yaitu anak yang dalam hal pemeliharaan hidupnya sehari-hari, biaya pendidikan dan sebagainya beralih tanggung jawabnya dari orang tua asal kepada orang tua angkatnya berdasarkan keput usan pengadilan.

Perbedaan penerima wasiat wajibah di Indonesia dengan negara-negara yang lain ini tidak terlepas dari perngaruh hukum Belanda BW) yang berlaku di Indonesia dimana disebutkan dalam BW bahwa anak angkat dan bapak angkat itu bisa saling mewarisi sebagaimana anak kandung.

Adanya wasiat wajibah untuk orang tua atau anak angkat yang berlaku di Indonesia ini tentunya diputuskan dengan mempertimbangkan rasa keadilan bagi anak dan orang tua angkat. Karena keduanya mempunyai ikatan hukum yang sah dan mempunyai hubungan layaknya hubungan antara orang tua dengan anak kandung dimana keduanya mempunyai hak dan kewajiban layaknya hak dan kewajiban anak

\section{Kesimpulan}

Dengan memperhatikan dan menempatkan al-Baqarah: 180 sebagai ayat muhkamah sebagaimana Abu Muslim alAsfihani dan mengkompromikannya dengan Hadis la wasiyyah li warith sebagai mukhassis membuat tidak ada status menghapus dan terhapus dalam ayat-ayat al-Qur'an. AlBaqarah:180 diarahkan petunjuknya pada kewajiban wasiat kepada kedua orang tua dan kerabat yang tidak mendapatkan warisan karena sesuatu hal māni', mahjūb, dan dhawi al-arḥām). Sedangkan, petunjuk hadis diarahkan pada larangan wasiat kepada ahli waris yang mendapatkan warisan.

Oleh karena itu, metode al-jam'u kompromi) dalam menghadapi dua nas yang kelihatannya terjadi kontradiksi

${ }^{24}$ Ibid., 179 
ta'arud) lebih tepat digunakan daripada naskh, sebagaimana kaidah Usul al-Fiqh yang dikemukakan oleh kelompok yang menentang tentang tidak adanya naskh dalam al Qur'an, yang berbunyi

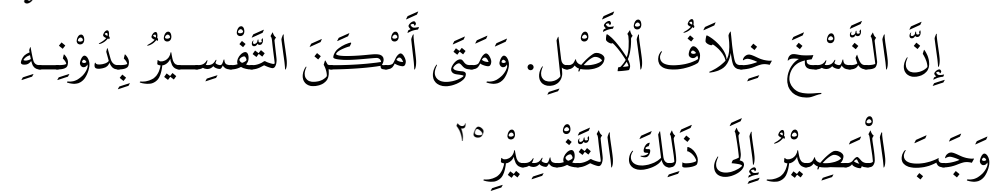

"Sesungguhnya metode naskh adalah menyalahi kaidah. Jika dapat dilakukan tafsir tanpa naskh, maka wajib kembali kepada tafsir itu"

Tradisi masyarakat Arab yang membagi harta menurut cara perjanjian atau half atau sumpah setia menjadi saudara seringkali menjadikan orang tua dan kerabat dekat sering kali tidak mendapatkan perhatian soal ini. Untuk itu, al-Qur'an hadir mempertegas hak orang tua dan kerabat dekat dengan ayat wasiat ini. Penegasan tentang bagian pasti turun setelah keimanan umat Islam menguat dan mental pemeluknya semakin siap menerima perintah agama. Dengan pembagian waris seperti diatur tersebut, maka Hadis hadir mempertegas, bahwa ahli waris tidak lagi diperbolehkan menerima wasiat. Dengan demikian, ketiga nașs tersebut saling terkait dan melengkapi. Prinsip tadrij berlaku dalam pemsyariatan waris dan wasiat.

${ }^{25}$ Abd al-Hamid Hakim, al-Bayān. (Djakarta: Sa'adijah Putera, 1972), 98. 


\section{Daftar Pustaka}

Ansari, Zakariya (al). Sharh al-Tahrïr. Surabaya: Maktabat Salim b. Sa'ad b. Nabhan, t.th.

Hakim, Abd al-Hamid. al-Bayān. Djakarta: Sa'adijah Putera, 1972.

Ibn Mājah, Muhammad ibn Yazid al-Qazwini. Sunan Ibn Mājah, Tahquiqq : Nāsīir al-Dīn al-Albāni. Riyad: Maktabah al-Ma'ärif li al-Nashr wa al-Tawzi', t.th.

Ibn Mandhur, Lisan al-'Arab. Juz 15, Beirut: Dar Sadir, t.th.

Ibn Salamah, Hibātullāh. al-Nāsikh wa al-Mansūkh Beirut: 'Alam al-Kutub, t.th.

Jawād, Aḥmad 'Abd (al). Ușūl 'Ilm al-Mawārith, Cet. II, Beirut: Dar al-Jayl, 1986.

Jurjāni (al). al-Ta'rifat. Mesir: Maṭba'ah al-Ḥamīdiyah, t.th.

Power, David S. Peralihan Kekayaan dan politik Kekuasaan Kritik Historis Hukum Waris. Jogjakarta: LKiS, 2001.

Qurtubi (al). al-Jami li Ahkam al-Qur'an. Vol. 2. Mesir: Dar alKatib al 'Arabiyah wa Nashr, 1967.

Razi, Muhammad Fakhruddin (al). Mafatih al Ghayb. Vol. 3. Beirut: Dar al Fikr, 1994.

Sabiq, Sayyid. Fiqh al Sunnah. Vol.3. Beirut: Dar al Fikr, 1977. Sayis, Muhammad Ali (al). Tafsir Ayat al-Ahkam, vol.1, Mesir: Muhammad Ali Subayh, t.th.

Zaydan, 'Abd al-Karim. al-Wajīz fi Ușūl al-Fiqh. Beirut: Muassasat al-Risalah, t.th.

Zuhayli, Wahbah (al). Al-Fiqh al-Isläm wa Adillatuh, vol. 9. Libanon: Dar al-Fikr, 1997. - Al-Tafsir al-Munir fi 'Aqìdah wa alSharī'ah wa al-Manhaj, vol. 27. Beirut: Dār al-Fikr, 1991. 